\title{
Preschool Design and School Readiness
}

\author{
Mariam Felani Shaari, Sabarinah Sh Ahmad \\ Centre of Architecture Studies, Faculty of Architecture, Planning \& Surveying, Universiti Teknologi MARA, 40450 \\ Shah Alam, Malaysia \\ mariamfelani87@gmail.com.my
}

\begin{abstract}
Preschool physical environments significantly affect children behavior and development. Efforts by the Malaysian Government to improve the quality of preschool education shows a lack of emphasis on the physical learning environment - despite overall improvements, school readiness remains moderate. In Malaysia, the impact of preschool physical learning environments on children's school readiness is still unclear; thus, this paper aims to investigate, highlight and conclude a clear theoretical relationship between these two aspects through literature review. Findings are hoped to lay the groundworks for future research into this matter to improve preschool education in Malaysia.

Keywords: Malaysian preschool education; Physical learning environment; Children school readiness; Children development

eISSN 2398-4279 @ 2018. The Authors. Published for AMER ABRA cE-Bs by e-International Publishing House, Ltd., UK. This is an open access article under the CC BY-NC-ND license (http://creativecommons.org/licenses/bync-nd/4.0/). Peer-review under responsibility of AMER (Association of Malaysian Environment-Behaviour Researchers), ABRA (Association of Behavioural Researchers on Asians) and CE-Bs (Centre for EnvironmentBehaviour Studies), Faculty of Architecture, Planning \& Surveying, Universiti Teknologi MARA, Malaysia.

DOI: https://doi.org/10.21834/ajqol.v3i10.106
\end{abstract}




\subsection{Introduction}

The preschool period is crucial for the development of one's emotional, social and cognitive abilities (Katz, 1999). Malaysia's Vision 2020 recognizes the importance of nurturing children from an early age. For preschools to maximize the development of children, learning programs must be supported by both aspects of the learning environment - social and physical (Loebach, 2005). However, unlike developed countries, the awareness among Malaysians regarding this is still lacking (Abbas, Othman \& Rahman, 2012). School readiness is also an important aspect of children education as it highlights the general level of physical and mental development the child has attained (Majzub \& Rashid, 2012). Therefore, school readiness should be a major agenda in the education of children in preschools to maximize their development for the betterment of the country.

\section{Aim and Objectives}

The paper aims to establish the link between the quality of preschool physical environments among Malaysian preschools and children school readiness.

The objectives are:

- To define physical learning environments of preschools and school readiness

- To assess the current state of preschool environments and school readiness of Malaysian public preschoolers

- To investigate the relationship between physical learning environment of preschool and primary school readiness

- To propose future direction of improvements of Malaysian public preschool learning environment

\subsection{Literature Review}

\subsection{Malaysian preschools}

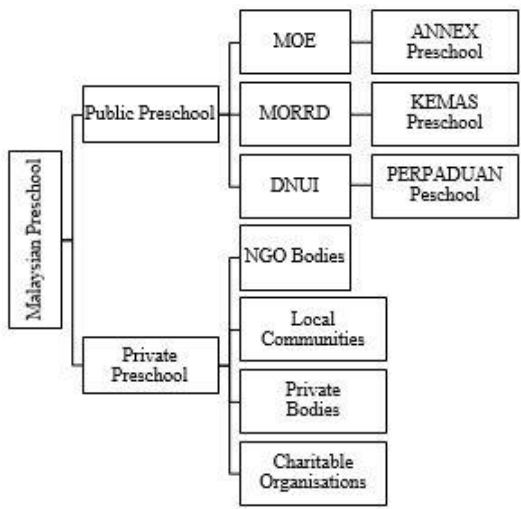

Figure 1: The Malaysian preschool system

(Source: Boon, 2010) 
Malaysian preschools or, "Tadika", serve children aged 4 to 6 . Figure 1 outlines the organization of preschools in Malaysia.

\subsection{Preschool learning environment}

The preschool learning environment comprises of social and the physical environments. A supportive learning environment embeds the learning and development opportunities into both the educational program and the physical form itself (Loebach, 2005).

\subsubsection{Social learning environment}

\subsubsection{Appropriate program and competent teachers}

It is crucial for a preschool to adopt curriculums that provide children with play opportunities as it plays a significant role in children learning (Loebach, 2005).

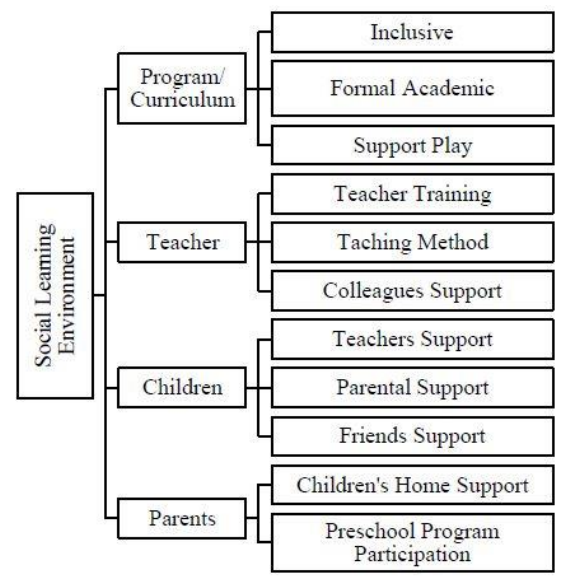

Figure 1: Elements of the preschool social learning environment

(Source: Cabell, Justice, McGinty, DeCoster \& Forston, 2015; Joseph, Ambika \& Williams, 2015; (Majzub, 2009; Loebach, 2004; Lieber, Capell, Sandall, Wolfberg, Horn \& Beckman, 1998)

Moreover, well-trained teachers who use the right methods to conduct the preschool program or curriculum, creating a stimulating and attractive environment, establishing social and educational inclusion in class and maintaining regular communication with parents are also crucial - it helps prevent separation and social anxiety (Joseph, Ambika \& Williams, 2015).

\subsubsection{Physical learning environment}

\subsubsection{Physical environment often overlooked}

Design elements are typically overlooked in discussions regarding the preschool physical learning environment (Joshi, 2008). Preschool education should not only concentrate on lesson planning, but also on spatial arrangements, which is equally important (Morrow, 2007). 
Children are significantly influenced by their physical as much as social settings (Maxwell \& Chmielewski, 2008).

Because preschool children are rapidly developing physically, cognitively, socially, and emotionally, their experience with the physical environment can have long-lasting effects on their development (Martin, 2004). Poor facilities and spatial quality also affect teachers' motivation and indirectly affect children education (Salleh, Kamaruzzaman \& Mahyuddin, 2013). Teachers will feel valued and motivated when they have access to good infrastructure, significantly improving their working performance (Uline \& Moran 2008), directly affecting children academic outcome.

\subsubsection{Supportive physical learning environment for children}

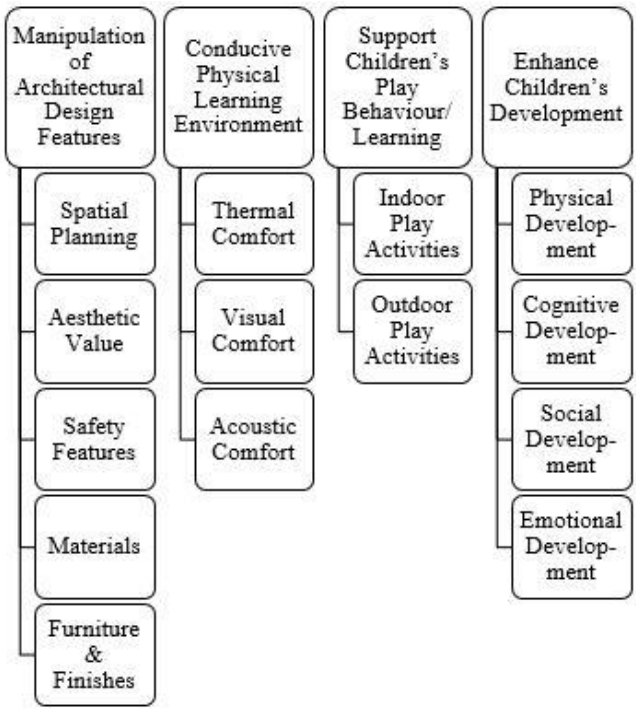

Figure 1: Supportive preschool physical learning environment for children.

(Source: Acar, 2014; Abbas, 2012; Abbas, Othman \& Rahman, 2012; Nair, Yusof \& Arumugam, 2012; Abbas \& Othman, 2011;

Abbas, Othman \& Rahman, 2010; Abbas \& Ghazali, 2010; Joshi, 2008; Maxwell, 2008; Badzis, 2006; Boldemann et al., 2006; Davison \& Lawson, 2006; Bratton, Ray, Rhine \& Jones, 2005; Fein, Plotnikoff, Wild \& Spence, 2004; Loebach, 2004; Fogg, 2001; Gurkaynak, 1996; Frost \& Wortham, 1988)

\subsubsection{Children's play behaviour: Learning through Play}

Children have natural inclinations to play - serving as a crucial mechanism for learning and development (Loebach, 2005). Play activities significantly enhance children's interest in class (Nair, Yusof \& Arumugam, 2012) through active use and exploration of their surrounding environment (Fogg, 2001). According to Habibe Acar (2014), "Play develops a child's talents and creative potential. It increases linguistic, mental, social, emotional, and motor skills; provides learning opportunities through trials and experiences that will be required throughout 
their lifetime".

More crucially, the continuous barriers that inhibit play activities in their environments could harm their physiology and psychology (Bratton, Ray, Rhine \& Jones, 2005). This condition shows that preschools should be designed with appropriate physical environments that stimulate and support play activities - learning should be fun and accidental, not forced upon (Badzis, 2006). A well-designed preschool should not be built solely to satisfy adult users but also tailored to children's needs, to enhance their developmental opportunities (Badzis, 2006).

\subsubsection{Outdoor play environments - Physical play}

Indoor play environment involves higher-level cognitive play that consists of engaging tasks and independent activities and is often more emphasized. Consequently, preschool outdoor spaces are often neglected in educational settings (Acar, 2014). Access to outdoor play environments is critical in triggering physical play activities (Davison \& Lawson, 2006), stimulate physical motor development and promote healthy behavior in children (Boldemann et al., 2006). Direct play interactions through touching, seeing and experiencing nature is also a major contributor to cognitive, motor, social and emotional development. Yielding to the sun during outdoor play will improve children health and reduce the risk of sick building syndrome - commonly related to low access to natural daylight and fresh air in indoor settings (Joshi, 2008).

\subsubsection{Physical Learning Environment and Children's Development}

Spatial arrangements and definition also influence children development; well-defined areas promote better learning and positive behaviors (Abbas \& Othman, 2011). Design and quality of material correlate with positive development among preschool children (Abbas \& Ghazali, 2010). Human comfort due to the physical environment is shown to affect child's play behavior, thus influencing learning (Abbas, Othman \& Rahman, 2012).

Studies show that physically planned environments affect a broad range of development positive behaviour development was seen in better-designed physical environments (Martin, 2004). Physical shortcomings hinder children development because it creates undesired behavioral obstacles, causing withdrawal and lack of integration with their surroundings (Gurkaynak, 1996).

Preschool physical environments affect children competency and development in many ways (Abbas, 2012; Abbas \& Ghazali, 2010; Abbas, Othman \& Rahman, 2010). The physical environment and children's development of cognitive and social competence are directly related (Maxwell, 2008).

\subsubsection{Interaction between the social and physical environment}

\subsubsection{Complementary role - social and physical learning environments}

Preschool objectives are achievable when there is a successful interaction between social and physical environments (Abbas, Othman \& Rahman, 2010). Teaching programs must be designed to work with the built infrastructure and vice-versa. Teaching and learning activities 
should not prevent access but utilize the designed facility. Well-designed preschools, equipped with good spatial and aesthetic qualities, good safety features, and appropriate use of materials, finishes and furniture, contributes to conducive environments for teaching and learning. Emphasis on both aspects of the learning environment will, therefore, maximize a child's development and learning.

\subsubsection{Preschool quality improvement}

\subsubsection{Developed country levels}

\subsection{Holistic improvement of preschool}

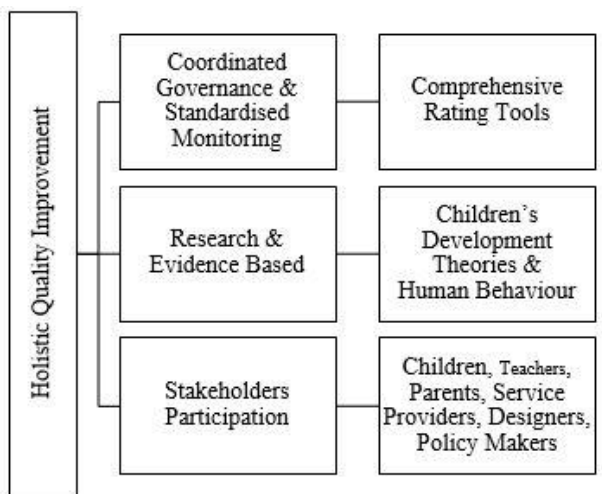

Figure 1: Holistic improvement of preschool

(Source: Abbas, Othman \& Rahman, 2012; Abbas \& Ghazali, 2010; Morrow, 2007)

As per Western approach, quality preschools must equally maximize the quality of social and physical learning environments to warrant positive and effective preschool settings that are safe and supportive for preschool users, especially children (Abbas, Othman \& Rahman, 2012; Abbas \& Ghazali, 2010; Morrow, 2007). Therefore, holistic improvements are defined as balanced improvements that utilize both types of environments - social and physical environments.

Most implementations made by developed countries are based on evidence from years of research in children developmental theories such as Piaget and Werner.

Designers who have minimal understanding of user behavior may repeat recurring design mistakes (Morrow, 2007). Ongoing studies related to children among Western countries prove that they are placing continuous efforts and initiatives in emphasizing the importance of children. If studies on children are still considered significant to them, Malaysia as a developing country should also acknowledge this and be more concerned. 


\subsubsection{Malaysian trend}

\subsubsection{Minimal emphasis on physical learning environment}

Malaysia's strategy to improve the quality of preschool education is highlighted in the Education Act 1996, Early Child Care and Education (ECCE) Policy, National Key Result Area (NKRA), 9th Malaysia Plan (9MP, 2006-2010) and 10th Malaysia Plan (10MP, 20112015). However, most policies are biased towards social environments. More emphasis on teacher training and curriculum were given, but minimal allocation to address the quality of physical environments (Abbas, Othman \& Rahman, 2012; Abbas \& Ghazali, 2010). If this persists, resources will be wasted to modify, maintain or reconstruct preschools with a properly designed physical environment to cater children needs. This situation can be avoided if the government seriously considers a more holistic approach - now rather than later.

\subsubsection{Basic standard physical design, facilities, materials and safety specification consideration}

Based on the ECCE Policy Implementation Review (2007), there are some concerning physical problems among Malaysian preschools - namely space allocation for the kitchen, dining and storage areas, furniture or facility allocation including cupboards, shoe racks and electrical fittings, lighting, ventilation, and water quality. Despite this, it was reported that teachers are satisfied with the kind of provision in their classrooms - showing a lack of awareness of the need for better physical design.

However, the assessments were only focused on teachers' satisfaction and basic needs. They do not show that current preschool physical environments maximize the learning process for children. Teacher satisfaction is also doubtful; they may not be aware of the appropriate physical learning environments regarding maximizing children development and children and teachers' performance. There is a lack of assessment of children satisfaction and facilities that support the developmental process and play learning activities.

\subsubsection{School readiness}

\subsubsection{Definition}

School readiness is a reflection of how well the child has mastered key development domains before they enter primary school. It encompasses all the basic aspects of a child's development - gross motor, social skills, emotional behaviors, intellectual and cognitive behaviors (Smart, Sanson, Baxter, Edwards \& Hayes, 2008), indicating how well the child has acquired abilities and milestones. School readiness varies due to preschool experience, preschool locations, and educational background as well as the socio-economic status of parent (Smart, Sanson, Baxter, Edwards \& Hayes, 2008). It can also act as a predictor of skill competency and future career success (Lee, Burkam, Ready, Honigman \& Meisels, 2006). 


\subsubsection{Benefits of school ready}

A ready child will adapt better to primary school (Majzub \& Rashid, 2012). A less ready child is more likely to have social, health and physical problems when participating in school activities (Majzub \& Rashid, 2012) and are more likely to become school dropouts, teen parents, engage in crime and have poor jobs (Duncan, Dowsett \& Claessens, 2007). Therefore, it is crucial for stakeholders to ensure that the design of preschools serve as a place or platform for children to develop normally and optimally. Preschool designs should help children to achieve their maximum potential (Majzub \& Rashid, 2012).

\subsubsection{Preschool physical learning environment and impact on primary school readiness}

Children spend most of their daytime in preschools. Their development and school readiness are mainly influenced by preschool environments as they interact with their surroundings. Many aspects of environmental behavior among Malaysian children have been shown to be influenced by the physical environment (Abbas, Othman \& Rahman, 2012; Abbas \& Othman, 2011).

School readiness is heavily influenced by preschool setting (Carlton \& Winsler, 1999). There is no doubt that the environment outside preschool - parental support and socioeconomic background - play a big role in influencing school readiness (Majzub \& Rashid, 2012). However, the importance of the preschool environment - social and physical, and its impact on children development should also be viewed as an important factor in enhancing school readiness. Physical environments affect the development of children and, therefore, their school readiness. Because there is a lack of a clear link between the preschool physical environment and school readiness in Malaysia, this research hopes to final establish this.

\subsubsection{Malaysian preschools - primary school readiness}

Recent studies showed that Malaysian Year 1 students have moderate levels of school readiness (Majzub \& Rashid, 2012). The study also showed that despite the emphasis on preschool social environments, a significant amount of children are still struggling to master Reading, Writing, and Arithmetic Skills (The 3R's) when they first attend primary school. This situation indicates that children's learning and developmental milestones during preschool years is not fully achieved as targeted.

Being a developing country, this is a major concern for Malaysia as the government could not afford to waste money on improvements that are not beneficial. It can be speculated that the lack of emphasis on preschool physical environment contributes to the non-readiness. Current efforts require prompt revision, calling for more improvement in the preschool physical aspect.

\subsection{Methodology}

Both quantitative and qualitative literature from various disciplines related to the title were reviewed. Three electronic databases were searched: Science Direct, Scopus, and Web of 
Knowledge, indexes Malaysian and international journals on a variety of preschool children related topics from 1923 to present. The following keywords were searched; Malaysian preschool education, physical learning environment, children school readiness and children development, using titles and descriptors.

\subsection{Findings and Discussions}

\subsection{Holistic improvements and research-based preschools}

Malaysia must appropriately adopt lesson learned from developed countries and adapt them to the local context - calling for more local research on this matter (Abbas, 2012). Improvements must also be holistic - not biased to social improvements alone.

\subsection{Physical environments must be tailored to support children's play behaviour and developmental needs}

The application of key design aspects should be tailored to support children's developmental needs. Given the immense amount of research done to highlight this issue, the Malaysian government can no longer turn a blind eye. Although there is a standard guideline to setup preschool in Malaysia - "Garis Panduan Penubuhan Tadika dan Taska" (Jabatan Perancangan Bandar dan Desa Semenanjung Malaysia, 2012), it is relatively new and shows no comprehensive requirements on the design aspect of the physical environment.

\subsection{Standard comprehensive physical environment quality guideline and monitoring among ministries}

Effective implementation of policies requires efficient governance mechanisms (Boon, 2010). There is no comprehensive physical learning environment assessment made by the Malaysian government. The existing preschools physical environment were not evaluated for its 'fit for purpose' for children. The status whether the provided infrastructures had fulfilled the children's unique demands and developmental needs, from children's view is unknown. This situation calls for more coordination among government ministries as to ensure their roles and responsibilities are laid out and coordinated properly, thus increase the provision of high quality of preschool, socially and physically.

\subsection{Local-based, quality rating tool for Malaysian preschools}

It is best to have a scale that is tailored to Malaysian local context. It will provide assistance to the government to develop accountable systems for recognizing and rewarding highquality preschool programs. Developing countries such as Malaysia do not necessarily need to come up with new tools. Available toolkits can be easily modified to meet local conditions. For example, modified versions of such toolkits were used in the Post Occupancy Evaluation Studies done in Malaysia on Healthcare (Abbas \& Ghazali, 2010) and Early Childhood Education (Abbas, Othman \& Rahman, 2010). Both the UK's NHS AEDET Evolution Toolkit (for evaluating the physical environment) and AEDET Evaluation Toolkit (for evaluating satisfaction levels amongst users) were used as the basis for data collection. In the latter, a 
study was conducted on the quality status of the physical environment of kindergartens. NSW CPERS toolkit was used as the basis for data collection.

\subsection{Participation from all stakeholders}

The participation of all stakeholders will significantly increase awareness of preschool learning environments and school readiness. Preschool children, teachers, service providers, parents, designers and policy makers, should participate and be consulted in the design process of preschool buildings (Majzub \& Rashid, 2012). Through participation, efforts in getting their feedbacks and increase awareness will ensure that every need is catered properly. Such participation is in line with the four principles of Convention on the Rights of Children (CRC) signed by the government. Children must not be discriminated, have a right to survival and development, their best interest must be a primary consideration, must be allowed as active participants in all matters affecting their lives and be free to express their opinions (Boon, 2010). In Malaysia, these efforts are growing but still lacks political will calling for more initiative.

The level of school readiness among preschool children must also be given more attention by the government. In western countries, school readiness is shown to be a good measure to gauge the development of children and their ability to contribute better in the future of their society. Careful consideration of preschool learning environment, social or physical, should maximize children's developmental potential, thus, contribute to the higher level of school ready for children.

\subsection{Conclusion}

There is a link between physical learning environment and children school readiness, and this can no longer be ignored among Malaysians. A properly designed physical environment will boost the development and education of children in Malaysia, contributing to improved school readiness among children and a better education system. Ensuring that preschool children are more school ready is key when designing a preschool. Children must be developed to their fullest potential while in preschool - they must be school ready. By helping children achieve this, we are significantly increasing their chances of success in the future which can be beneficial for the future generation of our country.

\section{Acknowledgement}

The authors would like to thank the Ministry of Higher Education, Malaysia, for the funding given under the Fundamental Research Grant Scheme (FRGS) ref: FRGS/1/2015/SSI11/UITM/02/10.

\section{References}

Abbas, M. Y. (2012). Children, Youth \& Environments (CYE): Lessons for Developing Countries? Procedia - Social 
and Behavioral Sciences, 38, 15-22.

Abbas, M. Y., \& Ghazali, R. (2010). Healing environment of pediatric wards. Procedia - Social and Behavioral Sciences, 5, 948-957.

Abbas, M. Y., \& Othman, M. (2011). Social Behaviours between Urban and Non-Urban Pre-School Children. Procedia-Social and Behavioral Sciences, 30, 2001-2009.

Abbas, M. Y., Othman, M., \& Rahman, P. Z. M. A. (2012). Pre-school Classroom Environment: Significant upon Childrens' Play Behaviour? Procedia - Social and Behavioral Sciences, 49, 47-65.

Acar, H. (2014). Learning Environments for Children in Outdoor Spaces. Procedia - Social and Behavioral Sciences, $141,846-853$.

Badzis, M. (2006). Child education: what should be optimal. Jurnal Pendidikan Islam, 12(1), 77-90.

Boldemann, C., Blennow, M., Dal, H., Mårtensson, F., Raustorp, A., Yuen, K., \& Wester, U. (2006). Impact of preschool environment upon children's physical activity and sun exposure. Preventive medicine, 42(4), 301-308.

Boon, N. S. (2010). Governance of Education Related ECCE Policies in Malaysia. International Journal of Child Care and Education Policy, 4(1), 45-57.

Bratton, S. C., Ray, D., Rhine, T., \& Jones, L. (2005). The Efficacy of Play Therapy With Children: A Meta-Analytic Review of Treatment Outcomes. Professional Psychology: Research and Practice, 36(4), 376-390.

Cabell, S. Q., Justice, L. M., McGinty, A. S., DeCoster, J., \& Forston, L. D. (2015). Teacher-child conversations in preschool classrooms: Contributions to children's vocabulary development. Early Childhood Research Quarterly, 30, 80-92.

Carlton, M. P., \& Winsler, A. (1999). School readiness: The need for a paradigm shift. School Psychology Review, (28), 338-352.

Curriculum Development Centre (2007). Early Childhood Care and Education Policy Implementation Review 2007. Ministry of Education Malaysia. Retrieved 9 April, 2015 from http://www.tadika.org/Malaysian ECCE Policy Review 24_Jan 2008.pdf

Davison, K. K., \& Lawson, C. T. (2006). Do attributes in the physical environment influence children's physical activity? A review of the literature. International journal of behavioral nutrition and physical activity, 3(1), 19.

Duncan, G.J., Dowsett, C.J., \& Claessens, A. (2007) School Readiness and later achievement. Developmental Psychology. 43 (6); $1428-1446$.

Fein, A.J., Plotnikoff, R.C., Wild, C., \& Spence, J.C. (2004). Perceived environment and physical activity in youth. International Journal of Behavioural Medicine 11(3), 135-142.

Fogg, P. (2001). A history professor engages student by giving them a role in the action. Chronicle of Higher Education. 48(12). A12-13.

Frost, J. L., \& Wortham, S. C. (1988). The Evolution of American Playgrounds. Young Children, 43(5), 19-28.

Gürkaynak, İ. (1996). Çocuklar, Çevreler, Eviçleri, Diğerlerinin Konut Sorunları, ed. Komut, E.M., TMMOB Yayınları, Ankara; 423-31.

Joseph, A. M., Ambika, K., \& Williams, S. (2015). Effectiveness of Clay Therapy on Anxiety Symptoms of Preschool Children. International Journal of Nursing Education, 7(1), 58-62.

Joshi, S. M. (2008). The sick building syndrome. Indian Journal of Occupational and Environmental Medicine, 12(2), 
61.

Katz, L. (1999). Another look at what young children should be learning. Campaign, IL: ERIC Clearinghouse on Elementary and Early Childhood Education, University of Illinois.

Lee, V.E., Burkam, D.T., Ready, D.D., Honigman J. \& Meisels, S.J. (2006). Full-day versus. Half-day kindergarten: In which program do children learn more? American Journal of Education 112(2), 163-208.

Lieber, J., Capell, K., Sandall, S. R., Wolfberg, P., Horn, E., \& Beckman, P. (1998). Inclusive preschool programs: Teachers' beliefs and practices. Early Childhood Research Quarterly, 13(1), 87-105.

Loebach, J. (2005). Designing learning environments for children: An affordance-based approach to providing developmentally appropriate settings.

Majzub, R. M. (2009). The development of a web based ecological assessment of school readiness (WEBEASR). Procedia - Social and Behavioral Sciences, 1(1), 2568-2572.

Majzub, R. M., \& Rashid, A. A. (2012). School Readiness among Preschool Children. Procedia - Social and Behavioral Sciences, 46, 3524-3529.

Martin, S. H. (2004). Environment-Behaviour Studies in the Classroom. The Journal of Design and Technology Education, 9 (2), 77-89.

Maxwell, L. E., \& Chmielewski, E. J. (2008). Environmental personalization and elementary school children's selfesteem. Journal of Environmental Psychology,28(2), 143-153.

Jabatan Perancangan Bandar dan Desa Semenanjung Malaysia (2012).Garis Panduan Penubuhan Tadika dan Taska. Putrajaya: Jabatan Perancangan Bandar dan Desa Semenanjung Malaysia, Kementerian Perumahan dan Kerajaan Tempatan.

Morrow, L. M. (2007). Developing literacy in preschool. New York, NY: Guildford Press.

Nair, S. M., Yusof, N. M., \& Arumugam, L. (2014). The Effects of Using the Play Method to Enhance the Mastery of Vocabulary among Preschool Children. Procedia - Social and Behavioral Sciences, 116, 3976-3982.

Salleh, N. M., Kamaruzzaman, S. N., \& Mahyuddin, N. (2013). Sick Building Symptoms among Children in Private Pre-schools in Malaysia: Association of Different Ventilation Strategies. Journal of Building Performance, 4(1).

Smart, D., Sanson, A., Baxter, J., Edwards, B. \& Hayes, A. (2008). Home-to-school-transitions for financially disadvantaged children. Sydney, NSW: The Smith Family.

Uline, C., \& Tschannen-Moran, M., (2008). The Walls Speak: The Interplay of Quality Facilities, School Climate and Student Achievement, Journal of Educational Administration, 46 (1), 55-73. 